\title{
Efficiency at Faculties of Economics in the Czech Public Higher Education Institutions: Two Different Approaches
}

\author{
Martin Flégl ${ }^{1} \&$ Kristýna Vltavská ${ }^{2}$ \\ 1 Department of Systems Engineering, Faculty of Economics and Management, Czech University of Life \\ Sciences Prague, Prague, Czech Republic \\ ${ }^{2}$ Department of Economic Statistics, University of Economics, Prague, Czech Republic \\ Correspondence: Martin Flégl, Department of Systems Engineering, Faculty of Economics and Management, \\ Czech University of Life Sciences Prague, Kamýcká 129, 165 21, Prague 6 - Suchdol, Czech Republic. Tel: \\ 420-224-382-380. E-mail: flegl@pef.czu.cz
}

Received: July 15, 2013 Accepted: August 21, 2013 Online Published: September 26, 2013

doi:10.5539/ies.v6n10p1 URL: http://dx.doi.org/10.5539/ies.v6n10p1

\begin{abstract}
The paper evaluates research and teaching efficiency at faculties of economics in the public higher education institutions in the Czech Republic. Evaluation is provided in two periods between the years 2006-2010 and 2007-2011. For this evaluation the Data Envelopment Analysis and Index approach are used. Data Envelopment Analysis measures research efficiency according to weighted inputs (average wages of academic staff, number of academic staff, and average number of students) to weighted output (RIV points). Teaching efficiency is measured according to weighted output (average number of absolvents). Index approach compares changes between productivity measured in two different ways (RIV points per academic staff, number of students per academic staff) and changes between average wages adjusted of average inflation rate. Although we evaluate research and teaching efficiency with different approaches, some similiraties can be found. Therefore, the detailed comparison of the results is provided. For the analysis we use data from the Ministry of Education, Youth and Sports (MŠMT) and from the Research, Development and Innovation Council (RVVI).
\end{abstract}

Keywords: competitiveness, data envelopment analysis, efficiency, higher education institutions, index approach, labour costs, productivity, RIV point

\section{Introduction}

\subsection{Czech Public Higher Education System}

The higher education system in the Czech Republic is divided into two types of the higher education institutions (hereafter: HEI) - university and nonuniversity. These types are additionally divided into three different categories according to the founder of a HEI: public, private and state. There are 45 public HEIs, 26 private HEIs and 2 state HEIs in the academic year 2012/2013. Most of them are situated in the capital city of Prague. The relevance of the private HEIs (which have been established since the academic year 2000/2001) has been rising because of the necessity of the augmentation of the number of the inhabitants with the university degree. The average annual growth of the number of students at the private HEIs (since the academic year 2000/2001) represents $27 \%$. On the contrary, the average annual growth of the number of students at the public HEIs reaches only $5 \%$ in the period in question. It implicates the increasing importance of the private HEIs in the Czech higher education system.

According to the announcement of the Ministry of Education, Youth and Sports (MŠMT) about the future reform in higher education (MŠMT, 2002) the efficiency in the Czech higher education is currently widely discussed. The reform proposes to divide higher education institutions into two main areas - research institutions, educational institutions. For this reason the research and educational efficiency of each HEI must be measured. The measurement goes along with the Strategic plan for 2011-2015 (MŠMT, 2010). This strategic plan covers many areas in the Czech public higher education system. Main priority areas are Quality and relevance, Openness and Efficiency and financing. The most crucial accent is devoted to challenges in labour mobility, research and efficiency in financing of HEIs. Strategic plan follows European education strategy (OECD, 2006), which covers the main challenges for the future of higher education in Europe (Yemini, 2012). 


\subsection{Evaluation of Research and Development}

The research and development in the Czech Republic is evaluated according to the "Methodology of Evaluation of Research Institutions Results and of Evaluation of Finished Programmes" published by the Research, Development and Innovation Council. This methodology is focused on results that were produced by each research organisation in the last five years. As Flégl, Zagata \& Brožová (2012) noted the official evaluation process is based on formalised procedures. Methodology differentiated between two categories of results: (I) results of the basic research - books, papers in scientific journals, conference proceedings and (II) results of applied research - patents, prototypes, industrial designs, maps, certified methods, and software. Each of these results gain a score, such as 20 or 40 points for a book, a paper in a journal with the impact factor (IF) receives a score within the interval 10-305 (according to the journal ranking), etc. The evaluation is executed for each organisation (university, the Academy of Sciences etc.) according to the relative share of the authors with the affiliation to the given organisation who created the outcome.

Afterwards each organization gains the total value of publication points called "RIV points". The achieved total number of RIV points indicates the scientific productivity of the organisation. The main idea of the evaluation constitutes information on research results that were created due to financial support from public resources, and also to gain an insight into the efficiency of such financing. Despite the fact that the official evaluation has many weaknesses, a different tool with the same level of exactness and complexity is not available.

\subsection{Measuring Efficiency in Education}

Worthington (2001) summarises the approaches that have been used for measuring efficiency in educational institutions between the years 1981 and 1998. The Data Envelopment Analysis (DEA) method was the dominant method here. DEA was developed by Charnes, Cooper \& Rhodes (1978) and currently has many applications especially in education.

Data Envelopment Analysis applications differ in their variety of Decision Making Units (DMUs). Some approaches use the whole university as a DMU (Avrikan, 2001; Melville \& Debasish, 1998; Rhodes \& Southwick, 1986). On the other side, some studies have used departments as DMUs (Harris, 1990; Kwimbere, 1987; Martín, 2006; Tomkins \& Green, 1988). Moreover, other authors use DEA to measure teaching and research performance in HEIs (Abbott \& Doucouliagos, 2003)

The structure of DEA models differs mainly according to their purpose. Most studies define inputs as teaching or research staff, research grants and the undergraduate student load. Outputs are thus contributions in academic journals, authored/edited books, and published works (Johnes \& Johnes, 1995). Furthermore, many authors specify different model structures. Kao and Hung (2008) add operating expenses and floor space as inputs, while Jablonský (2011) uses number of hours of direct and indirect teaching as outputs. Flégl et al. (2012) used personnel positions as inputs' categories in their approach. Thus, inputs are divided into three main categories: human, financial and material resources (Martín, 2006).

Another approach how to estimate the efficiency in education is based on using an Index approach which was presented by Vltavská and Fischer (2013). Index approach represents different option for measuring efficiency. The main idea is the comparison of productivity index and labour costs index. HEI is more competitive in case of higher increase of productivity (measured as the ratio of number of students per academic staff) than the increase of labour costs. This approach can be used for efficiency measuring of universities, faculties and departments too. From this point of view, Index approach has similar possibilities as DEA method. However contrary to the DEA method, where unit is efficient when its efficiency is equal to 1, unit in Index approach is efficient when the value of the annual growth of labour productivity is higher than the value of annual growth of labour costs.

The purpose of this paper is to evaluate the efficiency among the Czech faculties of economics (FE) regarding to Data Envelopment Analysis and Index approach. Each method has a different structure, therefore the detailed comparison of results must be provided. Data set includes labour costs, academic staff, students, absolvents and research points.

The paper is divided as follows: firstly we describe the Czech public higher education system and how efficiency measuring in education is mainly provided. Then we briefly continue with data specification, followed by model structure and the DEA and Index approach methodology. The main part of the paper is devoted to the results, which we analyse regarding to both methods and their detailed comparison. We conclude with a discussion and possible extension for the future work. 


\section{Method}

\subsection{Data Specification}

Both approaches use the same data, therefore the results can be compared. For the analysis we used the data from the Ministry of Education, Youth and Sports and the Research, Development and Innovation Council. This data set includes data on average wages of academic staff (MŠMT, 2013a), number of academic staff, average number of students, average number of absolvents (MŠMT, 2013b) and the sum of the RIV points using "Methodology of Evaluation of Research Institutions Results and of Evaluation of Finished Programmes 2011" (RVVI, 2011) and "Methodology of Evaluation of Research Institutions Results and of Evaluation of Finished Programmes 2012" (RVVI, 2012).

The analysis includes all the faculties of economics of the public HEIs in the Czech Republic. Because of the lack of the dataset needed for the analysis we had to exclude the College of Polytechnics Jihlava and the Institute of Technology and Business. These two HEIs were established in 2004, 2006 respectively and both are not included in the RIV dataset. The faculty of economics at University of South Bohemia is excluded from the first period because of the missing data in the year 2006. These FEs are evaluated according to labour costs (real average wage), academic staff (an average number of academic staff), students (an average number of students, i.e. bachelor and master students), absolvents (an average number of absolvents, i.e. bachelor and master students) and RIV points. The first three criteria are used as inputs for DEA model and RIV points as an output.

The analysis is divided into two periods (period between the years 2006-2010, and 2007-2011) according to the "Methodology of Evaluation of Research Institutions Results and of Evaluation of Finished Programmes".

\subsection{Data Envelopment Analysis}

Data Envelopment Analysis evaluates decision-making units (DMUs) against the best DMUs with the idea that: if one DMU can produce a certain level of output utilising a certain level of input, another DMU of equal scale should be capable of doing relatively the same. Data Envelopment Analysis is a non-linear programming model for the estimation of productive efficiency of DMUs, based on the relationship between multiple outputs and multiple inputs. These outputs and inputs are usually of various characteristics and of a variety of forms, which are difficult to measure. The efficiency of any decision-making unit is obtained as the maximum of a ratio of weighted outputs to weighted inputs, subject to the condition that the similar ratio for every DMU is less than or equal to 1 .

The simplest DEA model assumes constant returns to scale; this model is called the CCR model, according to its authors, Charnes et al. (1978). Let $y_{j H}$ be the amount of the $j^{\text {th }}$ output from unit $H$, and $x_{i H}$ be the amount of the $i^{\text {th }}$ input to the $k^{t h}$ unit. Using the CCR model, the DMU efficiency of a particular unit $H$ is calculated using the following linearisation of the original DEA model:

Primar model $\quad \Phi_{H}=\sum_{i=1}^{m} v_{i H} x_{i H} \rightarrow M I N$

subjected to

$$
\begin{aligned}
& \sum_{j m l}^{n} u_{j H} y_{j H}=1 \\
& \sum_{i=1}^{j} v_{i H} x_{i k}-\sum_{j=1}^{n} u_{j H} y_{j k} \geq 0, k=1,2, \mathrm{~K}, p \\
& u_{j H} \geq 0, j=1,2, \mathrm{~K}, n \quad a \quad v_{i H} \geq 0, i=1,2, \mathrm{~K}, m .
\end{aligned}
$$

Decision-making units $H$ is CCR efficient if $\Phi_{H}=1$. I, otherwise the DMU is not efficient.

Authors used Efficiency Measurement System (EMS) SW for calculation of the DEA model (Scheel, 2000).

\subsection{Index Approach}

As the second possible way how to evaluate the efficiency among the Czech faculties of economics we contemplate competitiveness analysis modified for the non-market industries (Vltavská \& Fischer, 2013). 


$$
C_{1} / Y_{1}<C_{0} / Y_{0},
$$

where $\quad C$...labour costs represent by the average wage

$Y$...number of students or RIV points.

After an adjustment we can set

$$
C_{1} / C_{0}<Y_{1} / Y_{0} .
$$

This could be interpreted as a requirement of slower increase of labour costs in comparison with the change of number of students or RIV points.

After the division of both parts of the inequation by the labour index represented by the index of number of academic staff $(L)$, we get

$$
C_{1} / C_{0}: L_{1} / L_{0}<Y_{1} / Y_{0}: L_{1} / L_{0},
$$

and after the algebraic adjustment

$$
C_{1} / L_{1}: C_{0} / L_{0}<Y_{1} / L_{1}: Y_{0} / L_{0} .
$$

This inequation signify that average labour costs should increase more slowly than labour productivity. Otherwise, we can consider compensation of employees (wages and salaries of the work force) as C. It implies that the inequation (4) demonstrates the relation between average wages and labour productivity. As we estimate real labour productivity by employing natural indicator, the average wage has to be real as well. For that reason we have to take into account inflation represented by consumer price index.

\section{Results}

\subsection{Index Approach}

We consider labour productivity in two different ways. Firstly, the ratio of RIV points per academic staff (productivity A). Secondly, the number of students per academic staff (productivity B). Labour costs are the same for both of the productivities. The results are presented in Table 1 and Table 2. One can see that there are some differences in labour productivities and average labour costs among FEs.

In the period between the years 2006 and 2010 the highest difference between labour costs and labour productivity A was achieved at the Faculty of Management and Economics at TBU - Tomas Bata University (728.77 percentage points). The decrease in labour costs was followed by the significant increase of the productivity A. It could be caused by the pressure of the University to the high scored publications. The same significant difference between labour costs and productivity A was registered at the Faculty of Economics and Management (CULS - Czech University of Life Science Prague) and at the Faculty of Business and Management (BUT - Brno University of Technology). On the other hand, only at two faculties at the University of Economics in Prague the increase of the labour costs is followed by the decrease of the productivity A. These two faculties are more teaching than research orientated.

From the point of view of the productivity B, at almost all faculties of economics is the increase in labour productivity higher than increase in average wages. It could be explained by the increase in number of students recorded in the period in question, which had started at the beginning of 2000s. Afterwards, due to the economic recession and fiscal restrictions the total budget for public universities decreased from 2009. Finally, the increase in the number of students is realized mainly in FE. However, there is a difference between individual FE. The highest difference between labour productivity and real labour costs is higher than 40 percentage points (Faculty of Informatics and Statistics, VŠE - University of Economics in Prague). On the other hand, higher decrease in productivity than decrease in the real labour costs was recorded at two FEs (Faculty of Social and Economic Studies, UJEP -Jan Evangelista Purkyne University in Usti nad Labem; Faculty of Management and Economics, TBU - Tomas Bata University). From our point of view the significant difference in the results of Faculty of Management and Economics (TBU) is very interesting. This underlines the fact we already mentioned. Faculty of Management and Economics (TBU) is more research oriented.

In the period between the years 2007 and 2011 the results of the difference between productivity A and labour costs are the same. The highest positive difference was achieved at the Faculty of Management and Economics (TBU) and the most significant negative difference was recorded at the Faculty of Finance and Accounting (VŠE). From the point of view of productivity B the results are quite different. The highest difference between labour productivity and real labour costs was achieved at the Faculty of Economics (UWB - University of West 
Bohemia). The significant decrease of labour costs was followed by the increase in labour productivity (it means that this faculty cut the budget but they admitted more students). Higher increase of labour costs than the productivity B was recorded at the Faculty of Economic (VŠE). Teaching cooperation between the individual faculties at the University of Economics might be a reason of this.

Table 1. Change in real labour productivity and average real labour costs, faculties of economics (2006 - 2010, annual growth, \%)

\begin{tabular}{|c|c|c|c|c|c|c|}
\hline Faculty & HEI & Costs & $\begin{array}{c}\text { Productivity } \\
\text { A }\end{array}$ & $\begin{array}{c}\text { Difference } \\
\text { A }\end{array}$ & $\begin{array}{c}\text { Productivity } \\
\text { B }\end{array}$ & $\begin{array}{c}\text { Difference } \\
\text { B }\end{array}$ \\
\hline of Social Sciences & $\mathrm{CU}$ & 3.47 & 74.85 & 71.38 & 20.19 & 16.72 \\
\hline of Social and Economic Studies & UJEP & -1.43 & 74.08 & 75.51 & -12.47 & -11.04 \\
\hline of Economics and Administration & MU & 1.39 & 209.22 & 207.83 & 18.01 & 16.62 \\
\hline $\begin{array}{l}\text { School of Business Administration } \\
\text { in Karvina }\end{array}$ & SU & 16.67 & 103.41 & 86.74 & 46.86 & 30.19 \\
\hline of Economics & UWB & -24.90 & 406.04 & 430.94 & 7.12 & 32.02 \\
\hline of Economics & TUL & 5.57 & 183.42 & 177.84 & 29.03 & 23.45 \\
\hline of Economics and Administration & UPA & -11.11 & 47.56 & 58.68 & -2.00 & 9.12 \\
\hline of Business and Management & BUT & -3.87 & 494.35 & 498.22 & -1.01 & 2.87 \\
\hline of Economics & VŠB-TUO & -5.22 & 264.17 & 269.39 & 16.59 & 21.81 \\
\hline of Management and Economics & TBU & -3.95 & 724.81 & 728.77 & -7.88 & -3.92 \\
\hline of Finance and Accounting & VŠE & 0.41 & -33.47 & -33.89 & 20.15 & 19.74 \\
\hline of International Relations & VŠE & 1.32 & -8.80 & -10.12 & 21.83 & 20.52 \\
\hline of Business Administration & VŠE & -5.32 & -4.15 & 1.17 & 0.08 & 5.40 \\
\hline of Informatics and Statistics & VŠE & 0.42 & 126.76 & 126.35 & 43.24 & 42.82 \\
\hline of Economics & VŠE & -4.18 & 6.99 & 11.17 & -1.45 & 2.72 \\
\hline of Management & VŠE & -9.89 & 20.98 & 30.87 & 14.34 & 24.23 \\
\hline of Economics and Management & CULS & 10.69 & 513.96 & 503.26 & 20.26 & 9.57 \\
\hline of Business and Economics & MENDELU & -9.61 & 83.87 & 93.48 & 9.88 & 19.49 \\
\hline
\end{tabular}

Source: Flégl and Vltavská (2013)

Note: All the abbreviations are described in Appendix. 
Table 2. Change in real labour productivity and average real labour costs, faculties of economics (2007 - 2011, annual growth, \%)

\begin{tabular}{|c|c|c|c|c|c|c|}
\hline Faculty & HEI & Costs & $\begin{array}{l}\text { Productivity } \\
\text { A }\end{array}$ & $\begin{array}{c}\text { Difference } \\
\mathbf{A}\end{array}$ & $\begin{array}{l}\text { Productivity } \\
\text { B }\end{array}$ & $\begin{array}{c}\text { Difference } \\
\text { B }\end{array}$ \\
\hline of Social Sciences & $\mathrm{CU}$ & 9.12 & 64.71 & 55.60 & 27.25 & 18.13 \\
\hline of Economics & USB & -6.06 & 94.51 & 100.57 & 5.95 & 12.01 \\
\hline of Social and Economic Studies & UJEP & -6.24 & 455.43 & 461.66 & -7.63 & -1.39 \\
\hline of Economics and Administration & MU & 3.78 & 106.52 & 102.74 & 19.51 & 15.73 \\
\hline $\begin{array}{l}\text { School of Business Administration in } \\
\text { Karvina }\end{array}$ & SU & 14.84 & 116.66 & 101.82 & 50.46 & 35.62 \\
\hline of Economics & UWB & -23.45 & 327.73 & 351.19 & 20.09 & 43.55 \\
\hline of Economics & TUL & -1.12 & 388.86 & 389.99 & 10.22 & 11.34 \\
\hline of Economics and Administration & UPA & -14.70 & 5.11 & 19.81 & 2.73 & 17.42 \\
\hline of Business and Management & BUT & -17.82 & 639.57 & 657.39 & 2.52 & 20.34 \\
\hline of Economics & VŠB-TUO & -19.58 & 161.16 & 180.74 & 3.45 & 23.02 \\
\hline of Management and Economics & TBU & -7.27 & 667.84 & 675.11 & -9.55 & -2.28 \\
\hline of Finance and Accounting & VŠE & 1.87 & -17.00 & -18.87 & 29.84 & 27.97 \\
\hline of International Relations & VŠE & 8.18 & -7.76 & -15.94 & 19.48 & 11.30 \\
\hline of Business Administration & VŠE & -7.12 & 3.36 & 10.48 & -5.12 & 2.00 \\
\hline of Informatics and Statistics & VŠE & 11.80 & 24.61 & 12.82 & 29.26 & 17.46 \\
\hline of Economics & VŠE & 3.91 & 26.70 & 22.80 & -5.17 & -9.07 \\
\hline of Management & VŠE & 1.53 & 63.35 & 61.82 & 29.12 & 27.59 \\
\hline of Economics and Management & CULS & -7.87 & 264.70 & 272.58 & 11.50 & 19.37 \\
\hline of Business and Economics & MENDELU & -19.26 & 94.72 & 113.98 & -6.68 & 12.58 \\
\hline
\end{tabular}

Source: Flégl and Vltavská (2013)

\subsection{Data Envelopment Analysis Method}

In our contribution, we use output-oriented DEA models. We want to evaluate labour productivity related to research and teaching activities evaluate that is why we chose the output orientation model. The aim is not to recommend cuts in labour costs nor in the academic staff, i.e. reduce input criteria of the model. Results give us the information as to which FEs are efficient in research and teaching, and which are not. We also assume the constant returns to scale and radial measure for the output. The more inputs FE has, the more output can produce, i.e. the more RIV points or absolvents FE can achieve. Model is calculated for the $2006-2010$ period and 2007-2011 subsequently.

Results are divided into two sections. Firstly, Table 3 contains results for research efficiency, i.e. inputs are labour costs, academic staff and number of students, and an output that refers to RIV points. Secondly, Table 4 contains results for teaching efficiency, i.e. inputs are the same as in the previous model, but an output refers to a number of absolvents.

Table 3 summarises the research efficiency results of DEA models. We calculated 4 different models according to the dataset. Model 1 used 2006-2010 dataset and contains all FEs (except USB - University of South Bohemia). Faculty of Social Science (CU - Charles University) is the only efficient faculty (efficiency score $100 \%$ ). This result is quite expected because the Faculty of Social Science represents an outlier in our dataset. Contrary to the rest of the HEIs and its FEs, Faculty of Social Science has few students but lots of RIV points. Thus, the other FEs are inefficient (efficiency score higher than 100\%). Faculty of Social and Economic Studies (UJEP) reached the lowest research efficiency. The reason of its inefficiency is very low level of the RIV points according to its inputs structure. 
Table 3. Research efficiency of faculties of economics in the Czech Republic, 2006-2010 and 2007-2011

\begin{tabular}{lccccc}
\hline \multicolumn{1}{c}{ Faculty } & HEI & Model 1 & Model 2 & Model 3 & Model 4 \\
\hline of Social Sciences & CU & $\mathbf{1 0 0 . 0 0 \%}$ & - & $\mathbf{1 0 0 . 0 0 \%}$ & - \\
of Economics & USB & - & - & $160.78 \%$ & $\mathbf{1 0 0 . 0 0 \%}$ \\
of Social and Economic Studies & UJEP & $1834.39 \%$ & $1069.48 \%$ & $1567.59 \%$ & $925.23 \%$ \\
of Economics and Administration & MU & $314.36 \%$ & $182.20 \%$ & $268.94 \%$ & $155.37 \%$ \\
School of Business & SU & $414.87 \%$ & $216.96 \%$ & $372.54 \%$ & $195.00 \%$ \\
Administration in Karvina & & & & & \\
of Economics & UWB & $1096.95 \%$ & $735.44 \%$ & $859.53 \%$ & $507.32 \%$ \\
of Economics & TUL & $303.03 \%$ & $155.12 \%$ & $293.96 \%$ & $174.45 \%$ \\
of Economics and Administration & UPA & $195.41 \%$ & $102.12 \%$ & $222.48 \%$ & $130.69 \%$ \\
of Business and Management & BUT & $425.41 \%$ & $231.69 \%$ & $298.77 \%$ & $173.30 \%$ \\
of Economics & VŠB-TUO & $236.16 \%$ & $105.05 \%$ & $256.47 \%$ & $104.46 \%$ \\
of Management and Economics & TBU & $285.79 \%$ & $149.60 \%$ & $235.41 \%$ & $129.62 \%$ \\
of Finance and Accounting & VŠE & $149.16 \%$ & $\mathbf{1 0 0 . 0 0 \%}$ & $192.70 \%$ & $113.73 \%$ \\
of International Relations & VŠE & $244.82 \%$ & $108.90 \%$ & $278.37 \%$ & $113.39 \%$ \\
of Business Administration & VŠE & $310.98 \%$ & $160.30 \%$ & $330.74 \%$ & $182.94 \%$ \\
of Informatics and Statistics & VŠE & $212.79 \%$ & $112.22 \%$ & $214.07 \%$ & $114.39 \%$ \\
of Economics & VŠE & $165.66 \%$ & $102.80 \%$ & $183.10 \%$ & $108.07 \%$ \\
of Management & VŠE & $292.01 \%$ & $186.32 \%$ & $394.87 \%$ & $233.06 \%$ \\
of Economics and Management & CULS & $376.06 \%$ & $167.28 \%$ & $292.69 \%$ & $138.10 \%$ \\
of Business and Economics & MENDELU & $195.35 \%$ & $\mathbf{1 0 0 . 0 0 \%}$ & $183.54 \%$ & $\mathbf{1 0 0 . 0 0 \%}$ \\
\hline
\end{tabular}

Because Faculty of Social Science (CU) represents an outlier in the Model 1, we calculated Model 2, which do not contain Faculty of Social Science (CU), and use 2006-2010 dataset. In this case, Faculty of Finance and Accounting (VSE), Faculty of International Relations (VŠE) and Faculty of Business and Economics (MENDELU - Mendel University in Brno) are research efficient in the period of 2006-2010. As in the previous model, Faculty of Social and Economic Studies (UJEP) reached the lowest research efficiency.

Similarly, as the first two models, we constructed Model 3 and 4, but the dataset 2007-2011 was used. Model 3 contains all FEs, including USB. The results are quite similar to Model 1, although the differences between FEs became smaller. Most of the FEs improved their efficiency score compare to the previous period. Because Faculty of Social Science (CU) represents outlier in this model again, we ran Model 4. Model 4 do not contain Faculty of Social Science (CU), and use similarly 2007-2011. Faculty of economics (USB) and Faculty of Business and Economics (MENDELU) are research efficient in this model.

First four models evaluated research efficiency of each FEs. Teaching efficiency for period 2006-2010 and 2007-2011 is calculated in Table 4. Model 5 used 2006-2010 dataset and contained all FEs (except USB from the same reason as in the model Model 1 and Model 2). Faculty of Management and Economics (TBU) and Faculty of Economics and Management (CULS) are the only teaching efficient faculties of economics. Faculty of Economics (VŠB-TUO - VŠB - Technical University of Ostrava) is very close to the efficient border (efficiency $100.40 \%$ ). Faculty of Economics and Administration (MU - Masaryk University) reached the lowest teaching efficiency $(212.78 \%)$.

The last calculated Model 6 used 2007-2011 dataset and contains all FEs (including USB). As in the previous period, Faculty of Management and Economics (TBU) and Faculty of Economics and Management (CULS) are teaching efficient faculties of economics. Besides these two faculties, Faculty of Economics (VŠB-TUO) is also teaching efficient. Differences between all FEs are smaller in the second period than in the first period. This corresponds with results comparison between 2006-2010 and 2007-2011 periods in research efficiency in Table 3. Faculty of Economics and Administration (MU) reached the lowest teaching efficiency again (183.77\%). 
Table 4. Teaching efficiency of faculties of economics in the Czech Republic, 2006-2010 and 2007-2011

\begin{tabular}{lccc}
\hline \multicolumn{1}{c}{ Faculty } & HEI & Model 5 & Model 6 \\
\hline of Social Sciences & CU & $190.90 \%$ & $162.78 \%$ \\
of Economics & USB & - & $130.03 \%$ \\
of Social and Economic Studies & UJEP & $162.37 \%$ & $132.51 \%$ \\
of Economics and Administration & MU & $212.78 \%$ & $183.77 \%$ \\
School of Business & SU & $164.70 \%$ & $155.53 \%$ \\
Administration in Karvina & & & \\
of Economics & UWB & $127.25 \%$ & $126.05 \%$ \\
of Economics & TUL & $143.15 \%$ & $122.37 \%$ \\
of Economics and Administration & UPA & $178.50 \%$ & $140.63 \%$ \\
of Business and Management & BUT & $167.10 \%$ & $109.38 \%$ \\
of Economics & VŠB-TUO & $100.40 \%$ & $\mathbf{1 0 0 . 0 0 \%}$ \\
of Management and Economics & TBU & $\mathbf{1 0 0 . 0 0 \%}$ & $\mathbf{1 0 0 . 0 0 \%}$ \\
of Finance and Accounting & VŠE & $145.33 \%$ & $128.40 \%$ \\
of International Relations & VŠE & $115.40 \%$ & $111.84 \%$ \\
of Business Administration & VŠE & $134.13 \%$ & $115.28 \%$ \\
of Informatics and Statistics & VŠE & $189.74 \%$ & $164.56 \%$ \\
of Economics & VŠE & $173.26 \%$ & $151.16 \%$ \\
of Management & VŠE & $135.87 \%$ & $128.61 \%$ \\
of Economics and Management & CULS & $\mathbf{1 0 0 . 0 0 \%}$ & $\mathbf{1 0 0 . 0 0 \%}$ \\
of Business and Economics & MENDELU & $143.47 \%$ & $128.57 \%$ \\
\hline & & & \\
\hline & & & \\
\hline
\end{tabular}

\subsection{Comparison of Approaches}

To be able to compare both approaches the same dataset had to be used. Although there is the different mathematical structure of the Index approach and the Data Envelopment Analysis, some similar results were recognisable. Efficiency of faculties of economics was divided into the 2006-2010 and 2007-2011 periods according to the RVVI methodology $(2011,2012)$.

In the first period both approaches showed some similiraties. Faculty of Social Science (CU) was determined as research efficient in DEA Model 1 and teaching inefficient (Model 5). Index approach confirmed this statement (see Table 1). The difference between labour productivity and labour costs reached 71.38 percentage points, compare to this difference in teaching efficiency (16.72 percentage points). Although the teaching efficiency was not negative, this result did not indicate high teaching efficiency (compare with Faculty of Social and Economic Studies - UJEP). The same results were given for the second period 2007-2011. Faculty of Social Science (CU) was research efficient (see DEA Model 3 in Table 3), compare to teaching inefficiency 162.78\% in DEA Model 6 (Table 4). Index approach (Table 2) indicated similar results as for the first period, i.e. the difference between labour productivity and labour costs reached 55.60 percentage points, compare to teaching efficiency 18.13 percentage points.

In addition, Index approach marked Faculty of Economics (UWB) as teaching efficient in both periods (32.02 and 43.55 percentage points respectively). DEA model confirmed the results; Faculty of Economics (UWB) was detected as research inefficient in both periods (see Table 3). Furthermore, Faculty of Economics (UWB) belonged to the most research inefficient FEs in the periods in question. This FE reached the efficiency score 1 096.95\% for the years 2006-2010 (Model 1) and 859.53\% for the years 2007-2011 (Model 3) Moreover, this faculty was almost teaching efficient with efficiencies 127.25\%, 126.05\% respectively (see Model 5 and 6 in Table 4).

On the other side, a few contradictions were also recognised. For example, Index approach indicated research efficiency, measured as the higher increase of labour productivity over labour costs, to Faculty of Management and Economics at Tomas Bata University (728.77 percentage points) and to Faculty of Economics and 
Management at the Czech University of Life Sciences Prague (503.26 percentage points) in the first period (Table 1). In contradiction, DEA model marked these faculties as reaserach inefficient. Faculty of Management and Economics at Tomas Bata University gained score $285.79 \%$ and Faculty of Economics and Management at the Czech University of Life Sciences Prague $376.06 \%$ (see Table 3). In contrary, DEA marked both faculties as teaching efficient (see Table 4). Although this contradiction, Index approach expressed improvement in teaching efficiency (higher increase of the teaching productivity over labour costs) for Faculty of Economics and Management (CULS) in the second period. Faculty of Economics and Management (CULS) reached teaching efficiency 19.37 percentage points, compare to 9.57 percentage points in the first period. Furthermore, research efficiency decreased to 272.58 percentage points. DEA Model 6 constantly referred to teaching efficiency for this faculty in the second period (Table 4) and Model 4 (Table 3) also reffered to increasing of research efficiency in the second period.

Finally, the difference between the results of DEA and Index approach was recorded in the case of Faculty of Finance and Accounting (VŠE) for 2006-2010 dataset. DEA Model 2 marked this FE as research efficient (Table $3)$. Contrary to this result, Index approach refers to inefficiency in research (-33.89 percentage points). Both approaches determined this faculty as research inefficient during the period 2007-2011. From the point of view of teaching efficiency of the faculty in question Index approach indicated Faculty of Finance and Accounting (VŠE) as teaching effective and DEA (Model 5 and Model 6) as teaching ineffective.

We pointed out for only a few examples of similar and different results for both approaches. Results for the remaining faculties were more or less the same, although the ranking of their efficiency scores reached a bit different position. This might be cause due to the very small differencies between some of the research and teaching efficiency results.

\section{Discussion}

As we mentioned in the introduction, the efficiency measurement in the Czech public higher education is important. Therefore, we can find similar papers that evaluated HEIs or FEs. For example most recently, Jablonský (2013) used DEA method and a similar model structure to evaluate research and teaching efficiency of faculties of economics. This DEA model focused only on the 2006-2010 period. Model used the same set of input variables for both analyses, i.e. a number of academic staff and labour costs. Research efficiency was evaluated according to the methodology RVVI (2011). Outputs were divided into three most important RIV categories (books, papers in journal with a positive impact factor, and papers in proceedings indexed in Web of Science) and the number of RIV points in general. Teaching efficiency was evaluated according to a number of students and absolvents. Study similarly showed research efficiency of Faculty of Social Science (CU), and teaching and research efficiency of Faculty of Management and Economics (TBU). Model also indicated high inefficiency of Faculty of Social and Economic Studies (UJEP). On the other side, different model structure meant a few different results as well.

Related to the approaches described in this paper, there are many ways to evaluate efficiency of Czech HEIs and FEs. Future reforms in education could reflect results of scientific studies. Also the Strategic plan for 2011-2015 (MŠMT, 2010), which focuses on improving financing efficiency of Czech Higher education, could reflect these results and results of another ongoing research. Adopted results could simplify the system of redistribution of financial resources from the MŠMT budget.

Future reforms and tendencies in Czech higher education system are widely discussed within the academic sphere. Therefore, each HEI can accept some principals earlier, before the whole package of reforms is adopted. Earlier acceptance can cause better efficiency score in teaching or/and reserach in the next measured period.

\section{Conclusion}

This paper dealt with the comparison of two different approaches estimating efficiency at the faculties of economics at the public higher education institutions in the Czech Republic in the periods 2006-2010 and 2007-2011. For this purpose we used DEA method and Index approach, which are based on the different mathematical basis. DEA method evaluates multiple inputs according to the multiple outputs. On the other hand, Index approach estimates efficiency according to the labour costs and labour productivity. For the estimation we employed same dataset, therefore the results were comparable.

Comparing the results we found out some similarities in the evaluation of efficiency at the Czech faculties of economics. Both approaches identified Faculty of Social Sciences (Charles University) as research and teaching efficient. This faculty represented the most research orientated faculty of economic in the Czech Republic. This faculty has few students but lots of RIV points and it represented outlier in our dataset. In case we excluded 
Faculty of Social Science (CU), so we were able to determine other faculties as effective. Faculty of Management and Economics (Tomas Bata University) was found as the research effective in both periods in question using Index approach. In case of DEA method this faculty was detected as teaching effective.

There are several advantages and disadvantages of the used approaches. Disadvantage of the DEA approach presents the possibility to identify DMU as efficient, even though all DMUs of the model are in fact inefficient, i.e. dataset is chosen wrong. Advantage of the DEA represents that the method itself proposes efficient levels of multiple inputs or outputs for inefficient DMUs. From this reason, DEA also describes how to reach the optimal solutions. On the other side, Index approach does not propose optimal solutions for inefficient faculties. Although this can be seen as a disadvantage, advantage represents possibility to decompose each parts of productivity. What is more, this decomposition enables a description, which productivity has the main influence.

\section{Acknowledgements}

This work was supported by the grant project of the Grant Agency of CULS Prague, No. 20131015, "Analysis and correction of rules for determining the amount of contributions and grants from MESH budget between higher education institutions based on DEA efficiency results.

\section{References}

Abbott, M., \& Doucouliagos, C. (2003). The Efficiency of Australian Universities: A Data Envelopment Analysis. Economics of Education Review, 22, 89-97. http://dx.doi.org/10.1016/S0272-7757(01)00068-1

Avrikan, N. (2001). Investigating Technical and Scale Efficiencies of Australian Universities Through Data Envelopment Analysis. Socio-Economic Planning Sciences, 35, 57-80.

Flégl, M., \& Vltavská, K. (2013). Comparison of Different Approaches to Estimate Efficiency at Faculties of Economics in Public Higher Education Institutions. Proceedings of the 10th International Conference on Efficiency and Responsibility in Education (ERIE 2013), Prague, pp. 136-144.

Flégl, M., Zagata, L., \& Brožová, H. (2012). Publication and research efficiency at the FEM CULS Prague Application of DEA. Proceedings of the 9th International Conference on Efficiency and Responsibility in Education (ERIE 2012), Prague, pp. 120-129.

Harris, G. T. (1990). Research Performance Indicators in Australian University Economics Departments. Economic Analysis and Policy, 20, 249-259.

Charnes, A., Cooper, W., \& Rhodes, E. (1978). Measuring the efficiency of decision-making units. European Journal of Operational Research, 2(6), 429-444. http://dx.doi.org/10.1016/0377-2217(78)90138-8

Jablonský, J. (2011). Models for Efficiency Evaluation in Education. Proceedings of the 8th International Conference on Efficiency and Responsibility in Education (Erie 2011), Prague, pp. 88-97.

Jablonský, J. (2013). Analysis of Research and Teaching Efficiency of Economic Faculties in the Czech Republic. Proceedings of the 10th International Conference on Efficiency and Responsibility in Education (Erie 2013), Prague, pp. 233-239.

Johnes, J., \& Johnes, G. (1995). Research Funding and Performance in U.K. University Departments of Economics: A Frontier Analysis. Economics of Education Review, 14(3), 301-314. http://dx.doi.org/10.1016/0272-7757(95)00008-8

Kao, Ch., \& Hung, H. T. (2008). Efficiency Analysis of University Departments: An Empirical Study. Omega, 36(4), 653-664. http://dx.doi.org/10.1016/j.omega.2006.02.003

Kwimbere, F. J. (1987). Measuring Efficiency in Non-for-profit Organizations: An Attempt to Evaluate Efficiency in Selected U.K. University Departments Using DEA. Msc. thesis, School of Management, University of Bath.

Martín, E. (2006). Efficiency and Quality in the Current Higher Education Context in Europe: An Application of the Data Envelopment Analysis Methodology to the Performance Assessment of the Departments at the University of Zaragoza. Quality in Higher Education, 12(1), 57-79. http://dx.doi.org/10.1080/13538320600685172

Melville, L., \& Debasish, D. (1998). The Relative Efficiencies of Canadian Universities: A DEA Perspective. Canadian Public Policy, 24(4), 485-511.

Ministry of Education, Youth and Sports (MŠMT). (2002). Bílá kniha - národní program rozvoje vzdělávání v $\begin{array}{lllll}\text { České } & \text { republice. } & \text { MŠMT, } & \text { Prague. } & \text { Retrieved }\end{array}$ 
http://www.msmt.cz/dokumenty/bila-kniha-narodni-program-rozvoje-vzdelavani-v-ceske-republice-formuje -vladni-strategii-v-oblasti-vzdelavani-strategie-odrazi-celospolecenske-zajmy-a-dava-konkretni-podnety-kpraci-skol

Ministry of Education, Youth and Sports (MŠMT). (2010). Dlouhodobý záměr vzdělávací a vědecké, výzkumné, vývojové a inovační, umělecké a další tvůrčí činnosti pro oblast vysokých škol na období 2011-2015. MŠMT, $\quad$ Prague. Retrieved from http://www.msmt.cz/vzdelavani/dlouhodoby-zamer-vzdelavaci-a-vedecke-vyzkumne-vyvojove-a

Ministry of Education, Youth and Sports (MŠMT). (2013a). Statistical Yearbook of Education - Employees and Labour Costs.

Ministry of Education, Youth and Sports (MŠMT). (2013b). Statistical Yearbook of Education - Performance Indicators.

OECD. (2006). OECD Reviews of Tertiary Education - The Czech Republic. OECD, Directorate for education, Education and training policy Division, France. Retrieved from http://www.oecd.org/education/skills-beyond-school/37730231.pdf

Research, Development and Innovation Council (RVVI). (2011). Methodology of Evaluation of Research Institutions Results and of Evaluation of Finished Programmes 2011 (in Czech only), Prague. Retrieved March 1, 2013, from http://www.vyzkum.cz/FrontClanek.aspx?idsekce=608098

Research, Development and Innovation Council (RVVI). (2012). Methodology of Evaluation of Research Institutions Results and of Evaluation of Finished Programmes 2012 (in Czech only), Prague. Retrieved March 1, 2013, from http://www.vyzkum.cz/FrontClanek.aspx?idsekce=650022

Rhodes, E., \& Southwick, L. (1986). Determinants of Efficiency in Public and Private Universities. Department of Economics, University of South Carolina.

Scheel, H. (2000). EMS: Efficiency Measurement System. Retrieved June 24, 2013, from http://www.holger-scheel.de/ems/

Tomkins, C., \& Green, R. (1988). An Experiment in the Use of Data Envelopment Analysis of Evaluating the Efficiency of UK University Departments of Accounting. Financial Accountability and Management, 4(2), 147-164. http://dx.doi.org/10.1111/j.1468-0408.1988.tb00296.x

Vltavská, K., \& Fischer, J. (2013). Is It Possible to Estimate Labour Productivity in the Czech Higher Education? Journal on Efficiency and Responsibility in Education and Science, 6(1), 1803-1617. http://dx.doi.org/10.7160/eriesj.2013.060104

Worthington, A. (2001). An Empirical Survey of Frontier Efficiency Measurement Techniques in Education. Education Economics, 9(3), 245-268. http://dx.doi.org/10.1080/09645290110086126

Yemini, M. (2012). Future Challenges in Higher Education - Bologna Experts' Community Case Study. International Education Studies, 5(5), 226-234. http://dx.doi.org/10.5539/ies.v5n5p226 


\section{Appendix}

Table 5. Abbreviations of the Czech higher education institutions

\begin{tabular}{ll}
\hline \multicolumn{1}{c}{ Abbreviation } & \multicolumn{1}{c}{ University } \\
\hline CULS & Czech University of Life Sciences Prague \\
USB & University of South Bohemia in České Budějovice \\
MU & Masaryk University \\
MENDELU & Mendel University in Brno \\
SU & Silesian University in Opava \\
TUL & Technical University of Liberec \\
UJEP & Jan Evangelista Purkyně University in Ústí nad Labem \\
CU & Charles University in Prague \\
UPA & University of Pardubice \\
TBU & Tomas Bata University in Zlín \\
VŠB-TUO & VŠB - Technical University of Ostrava \\
VŠE & University of Economics, Prague \\
BUT & Brno University of Technology \\
UWB & University of West Bohemia \\
\hline
\end{tabular}

\section{Copyrights}

Copyright for this article is retained by the author(s), with first publication rights granted to the journal.

This is an open-access article distributed under the terms and conditions of the Creative Commons Attribution license (http://creativecommons.org/licenses/by/3.0/). 